DOI:10.18276/sip.2016.45/2-12

\title{
Jacek Batóg*
}

Uniwersytet Szczeciński

\section{WPŁYW KRYZYSU GOSPODARCZEGO NA SYTUACJĘ EKONOMICZNO- -FINANSOWĄ PRZEDSIĘBIORSTW: UJĘCIE REGIONALNE}

\begin{abstract}
Streszczenie
W artykule przedstawiono wyniki badania wpływu światowego kryzysu gospodarczego, który rozpoczął się w 2007 roku, na sytuację ekonomiczno-finansową polskich przedsiębiorstw. Analiza przeprowadzona została w ujęciu regionalnym w latach 2006-2013. Ocenę efektów wpływu zjawisk kryzysowych oparto na obserwacji zmian kształtowania się dwóch podstawowych zmiennych - przychodów ze sprzedaży i liczby pracujących - charakteryzujących przedsiębiorstwa zatrudniające co najmniej 10 pracowników. Stosowana metoda badawcza nawiązuje do propozycji oceny przewagi konkurencyjnej znanej jako metoda BCG, w przypadku której zamiast zmian liczby pracujących rozpatrywane są wartości udziałów w rynku. W celu określenia podokresów korzystnej i niekorzystnej koniunktury gospodarczej wykorzystano Syntetyczny Wskaźnik Koniunktury Gospodarczej SI publikowany przez GUS oraz Wskaźnik Odczuć Ekonomicznych (Economic Sentiment Indicator - ESI) opracowany przez Eurostat ${ }^{1}$. Celem dodatkowym była analiza stabilności zmian sytuacji ekonomiczno-finansowej polskich przedsiębiorstw w badanym okresie oraz określenie stopnia podobieństwa województw pod względem tych zmian. Uzyskane wyniki wskazują na silny wpływ spowolnienia gospodarczego na sytuację ekonomiczną polskich przedsiębiorstw oraz wysoki stopień regionalnego zróżnicowania tego zjawiska.
\end{abstract}

Słowa kluczowe: sytuacja ekonomiczna przedsiębiorstw, analizy regionalne, wpływ kryzysu gospodarczego

* Adres e-mail: batog@wneiz.pl.

1 Zob. również wskaźnik koniunktury gospodarczej zaprezentowany w pracy (Batóg, 2009). 


\section{Wstęp}

W badaniach dotyczących oceny wpływu kryzysów gospodarczych na sytuację ekonomiczno-finansową przedsiębiorstw rozważane są najczęściej następujące czynniki (tzw. kanały wpływu) (Strategie przedsiębiorstw..., 2011, s. 6-7): spadek popytu na produkty i usługi wywołany niższą siłą nabywczą konsumentów z tytułu niższych lub w skrajnym przypadku braku dochodów, powodujący wzrost zapasów i spadek przychodów; wzrost kosztu kapitału obcego i utrudnienia w dostępie do finansowania zewnętrznego, co powoduje zaburzenia w bieżącej działalności firm oraz spadek inwestycji; pojawianie się zatorów płatniczych i wzrost poziomu zadłużenia przedsiębiorstw; zmniejszenie się eksportu wywołane redukcją popytu zagranicznego, skutkujące spadkiem przychodów ze sprzedaży; ograniczanie nakładów na rozwój i kreowanie nowych przedsięwzięć; spadek zysków będący wynikiem obniżania cen produktów i usług oraz zmniejszających się marży zysku, jak również zmiany postrzegania perspektyw rozwoju firmy skutkujące zmianami ich strategii rozwoju (Orłowski, 2009).

Negatywne efekty spowolnienia gospodarczego, a tym bardziej recesji, powodują często zmiany dotychczasowej polityki gospodarczej. Przykładem takiego powiązania może być między innymi przyjęta w Luksemburgu w lipcu 2008 roku ustawa o rozwoju gospodarczym niektórych regionów, która przewidywała stosowanie pomocy regionalnej polegającej głównie na dotacjach, dopłatach do oprocentowania, a także pomocy dla nowych MŚP. W 2009 roku podjęto kolejne kroki w celu poprawy aktywności gospodarczej przedsiębiorstw, przyjmując ustawę o wsparciu działalności badawczo-rozwojowej oraz ogłaszając projekt planu orientacji sektorowej dla stref działalności gospodarczej (Yuill, McMaster, Mirwaldt, 2009; Davies, Kah, Woods, 2010; Miszczak, 2010).

Stwierdzenie, że w okresach dekoniunktury gospodarczej pogorszeniu ulega sytuacja ekonomiczno-finansowa firm, nie wymaga przeprowadzania skomplikowanych analiz i zostało już wielokrotnie udowodnione. Pojawia się jednak pytanie, czy efekty wpływu kryzysu gospodarczego na sytuację ekonomiczno-finansową polskich przedsiębiorstw charakteryzują się zróżnicowaniem regionalnym. Determinuje ono podstawowy cel przeprowadzonego badania, którym jest weryfikacja hipotezy, według której zróżnicowanie to miało miejsce w okresie ostatniego spowolnienia gospodarczego. 


\section{Przegląd dotychczasowych badań}

Od drugiej połowy 2007 roku w krajach europejskich obserwujemy skutki kryzysu gospodarczego wywołanego na amerykańskim rynku kredytów hipotecznych. Najsilniejsze spowolnienie gospodarcze miało miejsce w roku 2008, osiągając apogeum pod koniec I kwartału 2009 roku. Następnie obserwowana była poprawa koniunktury gospodarczej do końca połowy 2011 roku oraz druga fala kryzysowa, która trwała praktycznie do końca 2012 roku. Aczkolwiek w całym tym okresie odczucia producentów i konsumentów w Polsce były zgodne co do kierunku zmian, to jednak w wybranych podokresach bardziej optymistyczne lub pesymistyczne w porównaniu do wszystkich krajów Unii Europejskiej (zob. rysunki 1-2)1. Na występowanie podobnych prawidłowości polegających na wysokim zróżnicowaniu stóp wzrostu gospodarczego w okresach kryzysów wskazywali między innymi autorzy pracy (Hideaki, Kose, Otrok, 2013), którzy za pomocą dynamicznego modelu czynnikowego poddali analizie 106 krajów w latach 1960-2010.

Rysunek 1. Syntetyczny Wskaźnik Koniunktury Gospodarczej SI dla Polski w okresie I kw. 2006 - IV kw. 2013

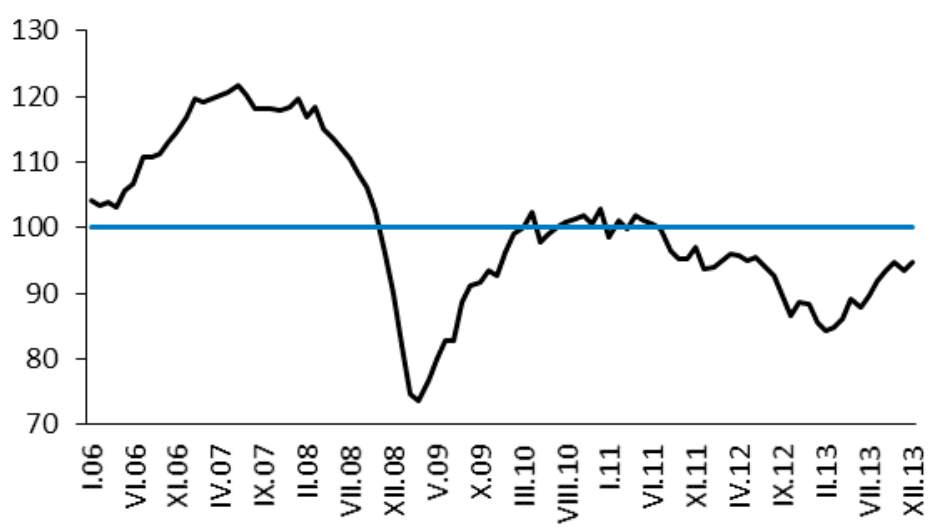

Źródło: GUS.

1 W pracy (Batóg, 2013) przeprowadzono analizę zgodności wahań koniunkturalnych 27 krajów członkowskich Unii Europejskiej w latach 1993-2011, która wskazała na stosunkowo silne ich zróżnicowanie. 
Rysunek 2. Wskaźnik Odczuć Ekonomicznych (Economic Sentiment Indicator - ESI) dla Polski i Unii Europejskiej w okresie I kw. 2006 - IV kw. 2013

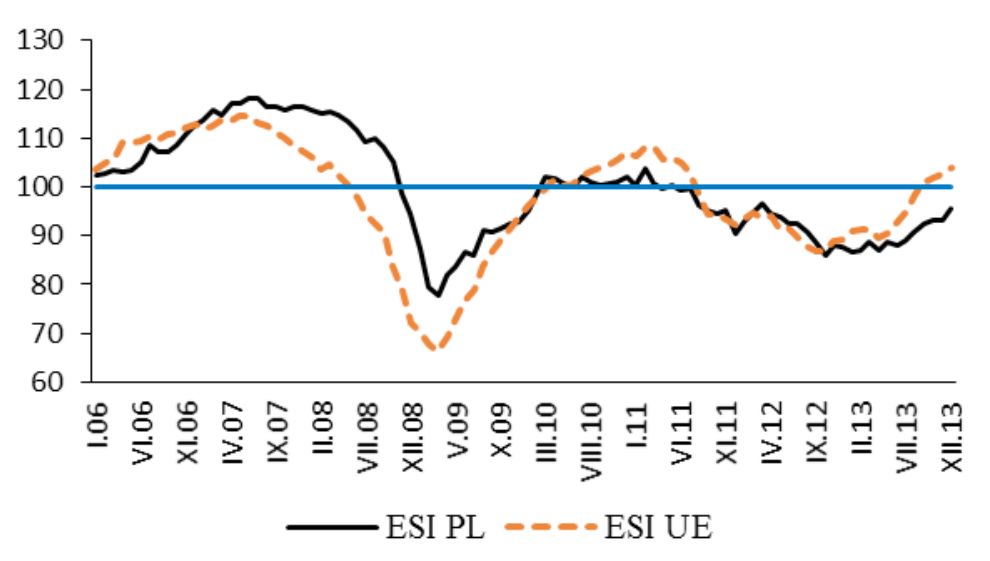

Źródło: Eurostat.

Zainteresowanie wielu autorów oprócz badania zgodności wahań koniunkturalnych obserwowanych na poziomie makroekonomicznym skierowane było również na wyjaśnienie przyczyn występowania zgodności przebiegu aktywności gospodarczej lub jej braku w ujęciu regionalnym. Wskazywano między innymi na silny związek między cyklami koniunkturalnymi i natężeniem procesów migracji (Larsson, Gaco, Sikström, 2009), uwarunkowania przestrzenne zależności stopnia synchronizacji regionalnych cykli koniunkturalnych z poziomem rozwoju regionów (Anagnostou, Panteladis, Tsiapa, 2012)를 wzrost synchronizacji regionalnych cykli koniunkturalnych wynikający ze wzrostu intensywności handlu zagranicznego oraz spadek tego zjawiska w przypadku wyższego zróżnicowania specjalizacji sektorowej i silnych wahań kursów walutowych (Tondl, Traistaru-Siedschlag, 2006) ${ }^{3}$. W pracach (Warżała, 2014; Hall, McDermott, 2004; Montoya, Haan, 2007) stwierdzono występowanie zróżnicowanych efektów wpływu kryzysów gospodarczych na wahania

2 W analizie dokonanej dla 200 jednostek NUTS II w latach 1980-2009 obserwowano zmiany PKB za pomocą filtru Hodricka-Prescotta, metody 3SLS oraz wykorzystując model panelowy VAR.

3 W tym badaniu obejmującym 208 jednostek NUTS II w latach 1989-2002 do analizy wartości dodanej brutto zastosowano model wielorównaniowy. 
koniunktury gospodarczej w badanych regionach ${ }^{4}$, natomiast w pracy (Duran, 2015) przedstawione zostały wyniki wskazujące na wzrost stopnia synchronizacji regionalnych cykli koniunkturalnych wynikający z podobieństwa struktury sektorowej, wielkości rynku i stopnia urbanizacji.

\section{Stosowane metody}

Zaproponowana koncepcja badania sytuacji ekonomiczno-finansowej województw w czasie opiera się na analizie dynamiki dwóch podstawowych kategorii: czynnika produkcji w postaci zatrudnienia mierzonego liczbą pracujących oraz przychodów ze sprzedaży (produktów, towarów i materiałów). Zaproponowana metodologia jest wzorowana na propozycji oceny przewagi konkurencyjnej firmy znanej jako metoda BCG, w przypadku której zamiast zmian zatrudnienia rozpatrywane są udziały w rynku (Batóg, 1995)5. Przyporządkowanie danego województwa do określonej kategorii pozwala nie tylko określić jego atrakcyjność poprzez ocenę pozycji w stosunku do innych województw, lecz umożliwia również obserwację zmian sytuacji poszczególnych województw w czasie.

Źródłem danych statystycznych były opracowania Bilansowe wyniki finansowe podmiotów gospodarczych wydane przez GUS w latach 2007-2014. Zaprezentowane w nich dane dotyczyły jednostek, w których liczba pracujących wynosiła 10 i więcej osób, prowadzących księgi rachunkowe lub podatkową księgę przychodów i rozchodów.

W celu określenia stabilności zmian analizowanych zmiennych zastosowano miarę zaproponowaną w pracy (Rutkowski, 1980, s. 6) o postaci:

$4 \quad$ R. Warżała stwierdził zróżnicowany wpływu kryzysów gospodarczych na wahania koniunktury gospodarczej w polskich województwach w latach 2000-2014, poddając analizie produkcję przemysłową i budowlaną za pomocą metody TRAMO/SEATS, filtru Christiano-Fitzgeralda, metody Bry-Boschana oraz współczynnika koherencji i korelacji krzyżowej. V.B. Hall i C.J. Mc Dermott, badając realny PKB dla 14 regionów Nowej Zelandii w latach 1977-2002 z wykorzystaniem nieparametrycznego współczynnika konkordancji, modelu logitowego oraz metody GMM, sformułowali wnioski o występowaniu asymetryczności cykli regionalnych w odniesieniu do zmian aktywności gospodarczej dla całej gospodarki oraz zależności stopnia zbieżności regionalnych cykli koniunkturalnych w zależności od odległości między regionami. Podobne wnioski, ale odnoszące się do skali makroekonomicznej, wskazujące na występowanie „efektu granicy”, sformułowane zostały na podstawie analizy 53 krajów Unii Europejskiej w latach 1975-2005 w pracy (Montoya, Haan, 2007) - por. wyniki uzyskane w pracy (Artis, Dreger, Kholodilin, 2009).

5 W pracy (Economic Crisis..., 2014) przeprowadzono analizę odporności regionów Unii Europejskiej na kryzys gospodarczy, wykorzystując zatrudnienie i PKB. 


$$
W S_{i}=\sqrt{\frac{\sum_{t=1}^{n}\left(r_{t}^{i}-r_{g}^{i}\right)^{2}}{n}} * 100
$$

gdzie:

$r_{t}^{i}$-indeks łańcuchowy zmiennej dla obiektu $i$ w okresie $t(t=1,2, \ldots, n)$, $r_{g}^{i}$ - średnia geometryczna z indeksów $r_{t}$ dla obiektu $i$.

\section{Wyniki empiryczne}

Zmiany zatrudnienia i przychodów ze sprzedaży polskich przedsiębiorstw w okresie obserwowanego w ostatnich latach spowolnienia gospodarczego miały nieco odmienny charakter. Ich poziom zmniejszył się znacząco w latach 2008-2009, przy czym tylko w przypadku liczby pracujących odnotowany został ujemny przyrost w roku 2009 w stosunku do roku poprzedniego. W kolejnych dwóch latach obserwowaliśmy wzrost przychodów ze sprzedaży, a w latach 2012-2013 ich kolejny spadek spowodowany drugą falą kryzysu gospodarczego. Poziom zatrudnienia uległ poprawie tylko w 2010 roku, utrzymując się w kolejnych trzech latach na zbliżonym poziomie (zob. rysunek 3).

Rysunek 3. Zmiany przychodów ze sprzedaży i liczby pracujących w polskich przedsiębiorstwach w latach 2006-2013 [\%]

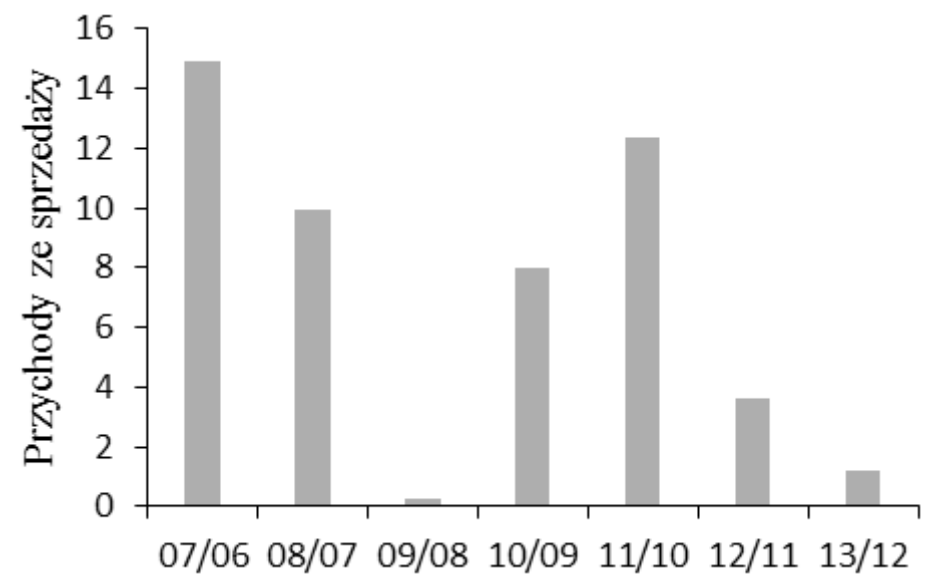




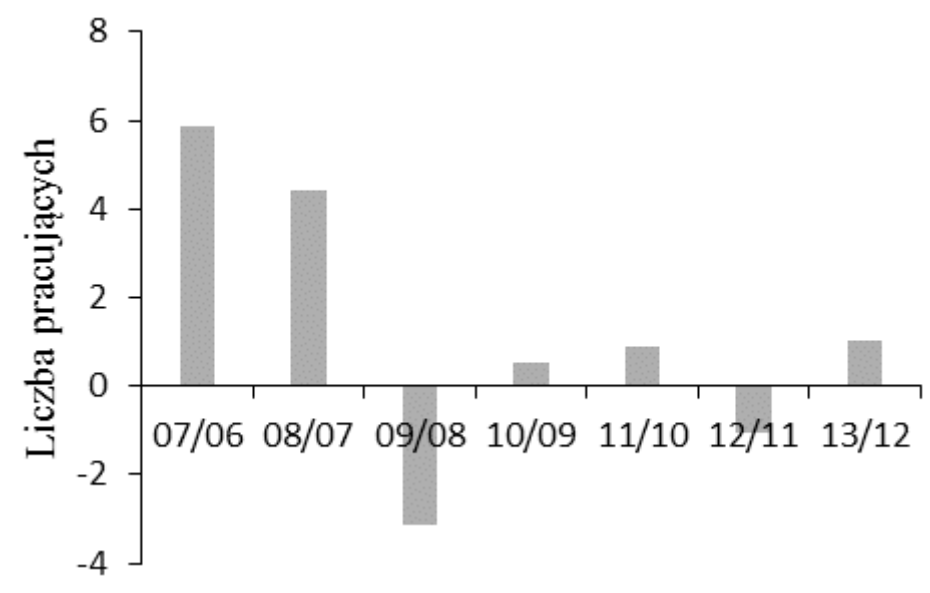

Źródło: obliczenia własne na podstawie danych GUS.

Analiza zmian obu rozpatrywanych zmiennych łącznie pozwala zauważyć silną odmienność kształtowania się długookresowych zmian sytuacji ekonomiczno-finansowej przedsiębiorstw w poszczególnych województwach. Jeżeli przyjmiemy rok 2006 za bazowy i obliczymy przyrosty zmiennych o stałej podstawie, to zauważymy, że prawie wszystkie województwa charakteryzowały się ujemnymi wartościami zmian obu zmiennych w roku 2007 (z wyjątkiem wielkopolskiego), ale w kolejnych latach ich „ścieżki rozwoju” były już zróżnicowane. We wszystkich województwach rosły przychody ze sprzedaży, podczas gdy wzrost zatrudnienia odnotowany został wyłącznie w województwach: dolnośląskim, lubelskim, małopolskim, mazowieckim i wielkopolskim. Najbardziej skutki kryzysu gospodarczego odczuły przedsiębiorstwa w województwach: opolskim, podlaskim, śląskim, świętokrzyskim, warmińsko-mazurskim i zachodniopomorskim. Warto przy tym zauważyć, że punktem odniesienia (początek układu współrzędnych) w powyższej analizie była zmiana zmiennych obserwowana w roku 2013 w stosunku do roku 2006, obliczona dla wszystkich podmiotów objętych badaniem (zob. rysunek 4). 
Rysunek 4. Zmiany sytuacji ekonomiczno-finansowej przedsiębiorstw w wybranych województwach w latach 2006-2013 (przyrosty względne o stałej podstawie wyrażone w \%)

\section{Lubuskie}

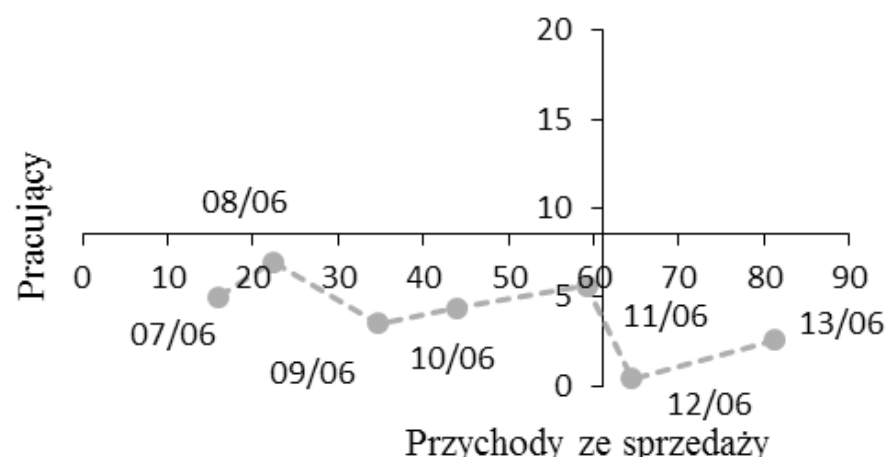

Wielkopolskie

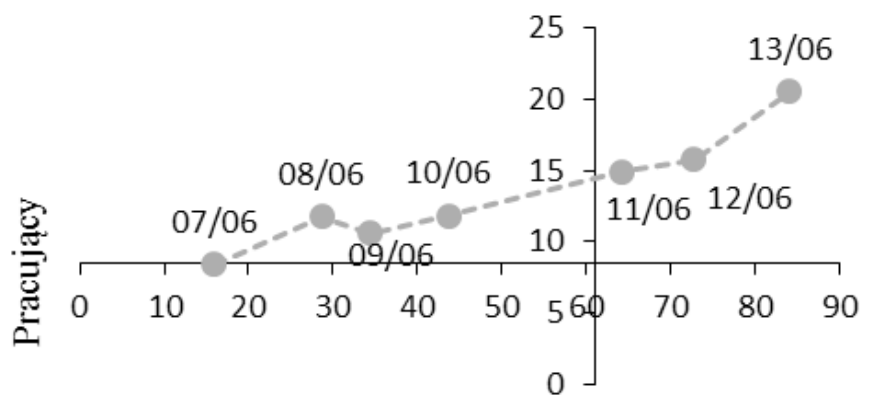

Przychody ze sprzedaży

\section{Opolskie}

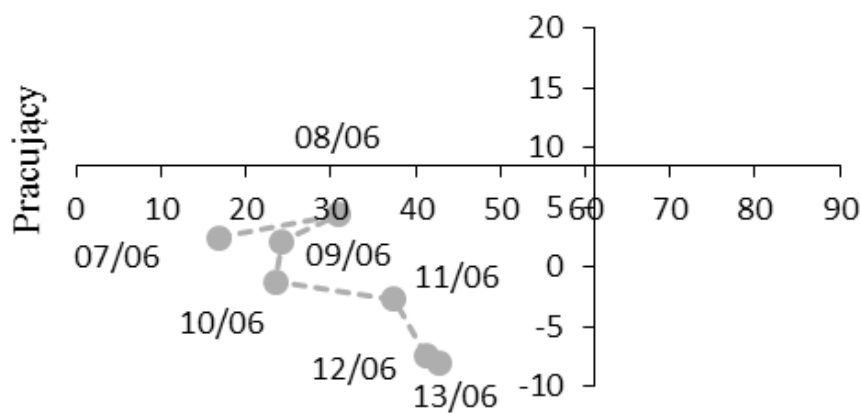

Przychody ze sprzedaży

Źródło: obliczenia własne na podstawie danych GUS. 
Obserwacja długookresowych zmian skutków kryzysu gospodarczego w ujęciu regionalnym pozwala wyróżnić 4 grupy województw. Pierwszą z nich stanowią województwa: dolnośląskie, lubelskie i wielkopolskie, które z trzeciej ćwiartki awansowały do ćwiartki pierwszej powyższych diagramów. Drugą województwa: małopolskie i mazowieckie, które z trzeciej ćwiartki przesunęły się do ćwiartki czwartej. Trzecią zaś województwa: kujawsko-pomorskie, lubuskie, łódzkie, podkarpackie i pomorskie, które zmieniły pozycję z trzeciej ćwiartki na drugą, podczas gdy województwa: opolskie, podlaskie, śląskie, świętokrzyskie, warmińsko-mazurskie i zachodniopomorskie występowały w trzeciej ćwiartce przez cały analizowany okres. Ta ostatnia grupa województw charakteryzowała się we wszystkich latach niższymi przyrostami lub wyższymi spadkami przychodów i pracujących (zob. rysunek 5)

Rysunek 5. Klasyfikacja województw według długookresowych zmian sytuacji ekonomiczno-finansowej przedsiębiorstw w latach 2006-2013

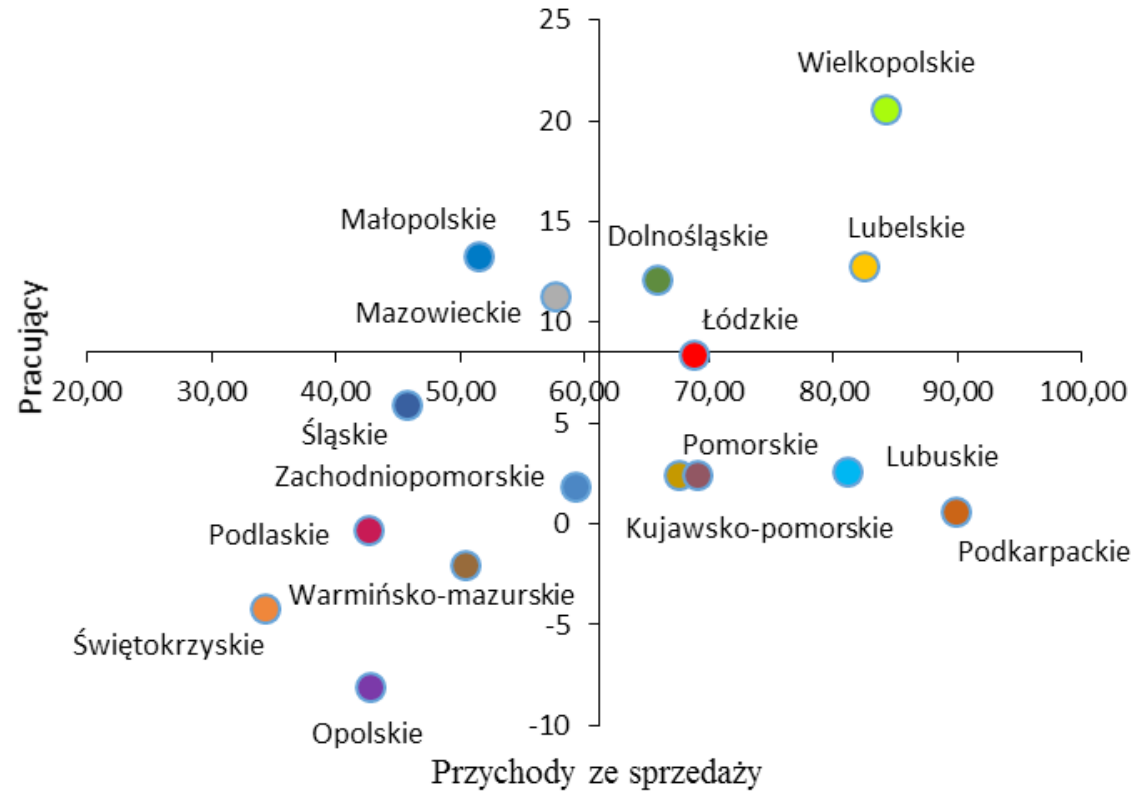

Źródło: obliczenia własne na podstawie danych GUS.

6 Jak wskazywali autorzy pracy (Barnett, Lewis, 1994), tego typu wykresy w połączeniu z wykresem obrazującym uporządkowane odległości Mahalanobisa stanowią podstawowe narzędzie wykrywania obserwacji nietypowych. 
Kolejną cechą, która opisuje duże różnice w zakresie wpływu pogorszenia koniunktury gospodarczej na sytuację polskich przedsiębiorstw, jest stopień zróżnicowania zachodzących zmian badanych zmiennych. Na rysunku 6 zaprezentowano to zróżnicowanie dla dwóch wybranych województw: małopolskiego i lubelskiego, przy czym zmiany dla tych województw zostały obliczone w stosunku do wszystkich podmiotów objętych badaniem dla każdego roku oddzielnie. Wyraźnie widoczne jest znacznie większe zróżnicowanie zmian przychodów ze sprzedaży i liczby pracujących dla województwa lubelskiego, zwłaszcza w przypadku tej pierwszej zmiennej.

Rysunek 6. Stopień regionalnego zróżnicowania zmian sytuacji ekonomiczno-finansowej przedsiębiorstw

\section{Malopolskie}

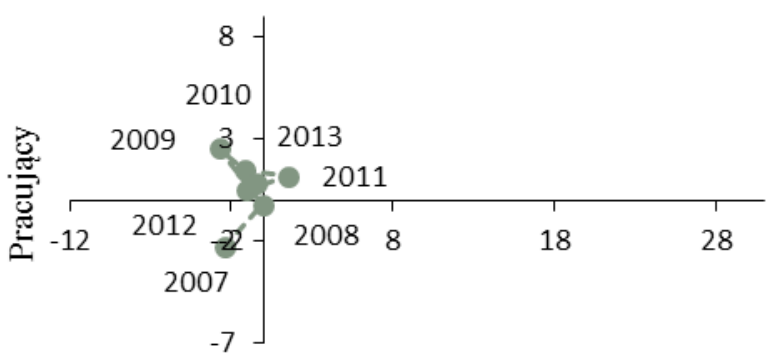

Przychody ze sprzedaży

\section{Lubelskie}

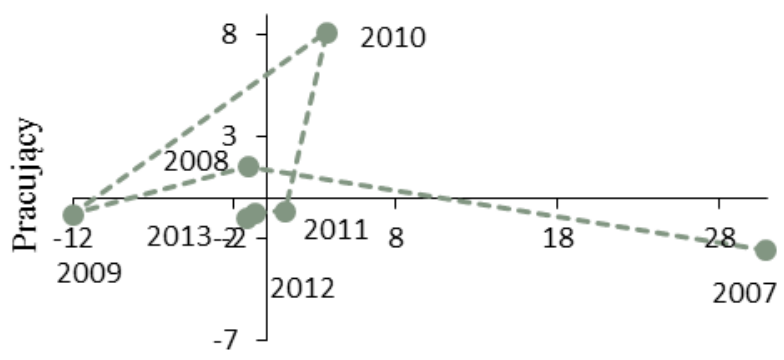

Przychody ze sprzedaży

Źródło: obliczenia własne na podstawie danych GUS. 
Powyższa analiza pozwala w pewnym stopniu ocenić odporność gospodarki danego województwa na negatywne impulsy pochodzące $\mathrm{z}$ otoczenia.

Na rysunku 7 zaprezentowano stabilność zmian obu badanych zmiennych w poszczególnych województwach obliczoną w całym rozpatrywanym okresie, która była znacznie wyższa w przypadku liczby pracujących.

Rysunek 7. Wskaźnik stabilności zmian przychodów ze sprzedaży i liczby pracujących w przedsiębiorstwach w poszczególnych województwach (2006-2013)
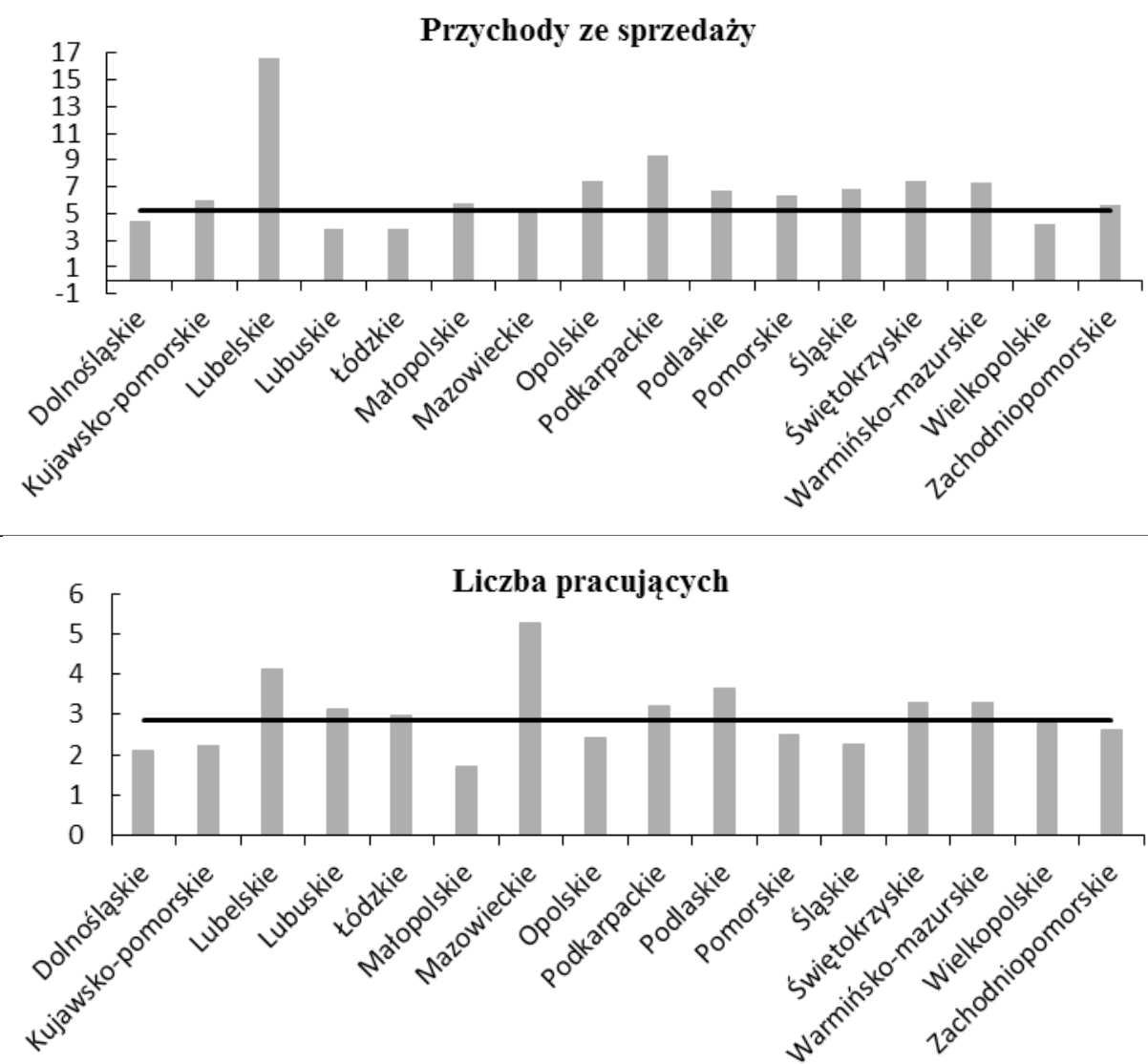

Źródło: obliczenia własne na podstawie danych GUS.

Warto przy tym zwrócić uwagę na stosunkowo silne zróżnicowanie zmian przychodów dla województwa lubelskiego, które było już zresztą sygnalizowane w poprzednich analizach, oraz liczby pracujących dla województwa mazowieckiego. 


\section{Podsumowanie}

W latach 2006-2013 polską gospodarkę, podobnie jak pozostałe kraje Unii Europejskiej, charakteryzowały gwałtowne zmiany koniunktury gospodarczej. Odnosiło się to również do sytuacji gospodarczej badanej w ujęciu regionalnym. $\mathrm{W}$ analizowanym okresie przebieg zmian sytuacji ekonomiczno-finansowej przedsiębiorstw wywołanych skutkami kryzysu gospodarczego w przypadku poszczególnych polskich województw był silnie zróżnicowany. Najniższy poziom skorelowania zmian sytuacji ekonomiczno-finansowej przedsiębiorstw z pozostałymi województwami wykazywały województwa: podkarpackie, lubuskie i pomorskie jeżeli weźmiemy pod uwagę zmiany krótkookresowe, oraz świętokrzyskie, opolskie i podlaskie - gdy uwzględnimy zmiany długookresowe. Jednocześnie obserwowana była wysoka zgodność zmian kondycji przedsiębiorstw w poszczególnych województwach w odniesieniu do całej gospodarki. Wyjątek stanowiły: w przypadku zmian krótkookresowych województwo lubuskie, a w przypadku zmian długookresowych województwo świętokrzyskie. W dalszych badaniach uwzględnić można inne zmienne charakteryzujące sytuację ekonomiczno-finansową przedsiębiorstw, takie jak nakłady inwestycyjne, aktywa, zadłużenie, płynność, rentowność, wydajność pracy, jak również ocenić wpływ takich czynników jak specjalizacja sektorowa. Rozważyć też można wykorzystanie innych metod badawczych, co pozwoliłoby zweryfikować hipotezę o odporności uzyskiwanych wyników na stosowanie zróżnicowanych metod analizy. Należy jednak przy tym uwzględnić fakt, że w dłuższym okresie zmiana poszczególnych zmiennych może być również spowodowana zmianą stosowanej technologii oraz zmianą struktury sektorowej gospodarki.

\section{Literatura}

Anagnostou, A., Panteladis, I., Tsiapa, M. (2012). Business Cycle Synchronisation in the EU Regions. Pobrane z: http://www.academia.edu/2687808/Business_cycle_synchronization_in_the_EU_regions (10.07.2015).

Artis, M., Dreger, Ch., Kholodilin, K. (2009). Common and Spatial Drivers in Regional Business Cycles. Deutsches Institut für Wirtschaftsforschung, Discussion Paper No. 859, Berlin.

Barnett, V., Lewis T. (1994). Outliers in Statistical Data. Chichester: John Wiley \& Sons. Batóg, J. (1995). Ocena pozycji konkurencyjnej firmy na rynku. W: Mikroekonometria w teorii i praktyce. Materiaty. Konferencje nr 6 (s. 219-225). Szczecin: Wyd. Naukowe US. 
Batóg, J. (2009). Analiza porównawcza wybranych formut wskaźników koniunktury w kontekście przewidywania dochodów jednostek samorzadu terytorialnego. W: J. Garczarczyk (red.), Rynek ustug finansowych a koniunktura gospodarcza (s. 329-339). Warszawa: CeDeWu.

Batóg, J. (2013). Analiza zgodności wahań koniunkturalnych w krajach Unii Europejskiej. W: B. Pawełek (red.), Zastosowanie metod ilościowych i jakościowych w modelowaniu i prognozowaniu zjawisk społeczno-gospodarczych (s. 34-42). Kraków: Wyd. UE w Krakowie. Bilansowe wyniki finansowe podmiotów gospodarczych (2007, 2008, 2009, 2010, 2011, 2012, 2013, 2014). Warszawa: Główny Urząd Statystyczny.

Davies, S., Kah, S., Woods, Ch. (2010). Regional Dimensions of the Financial and Economic Crisis. European Policy Research Paper No. 70.

Duran, H.E. (2015). Dynamics of Business Cycle Synchronization within Turkey. Turkish Economic Association, Discussion Paper No. 1. Pobrane z: https://ideas.repec.org/p/ tek/wpaper/2015-01.html (18.08.2015).

Economic Crisis: Resilience of Regions (2014). Pobrane z: http://www.espon.eu/main/ Menu_Projects/Menu_AppliedResearch/ECR2.html (20.08.2015).

Hideaki, H., Kose, A., Otrok, Ch. (2013). Regionalization vs. Globalization. The Research Institute of Economy, Trade and Industry, Discussion Paper Series No. 13-E-004.

Hall, V.B., McDermott, C.J. (2004). Regional Business Cycles in New Zealand: Do They Exist? What Might Drive Them? Motu Working Paper 04-10, Motu Economic and Public Policy Research.

Larsson, A., Gaco, N., Sikström, H. (2009). Aggregate and Regional Business Cycle Synchronisation in the Nordic Countries. Swedish Institute for European Policy Studies, Report No. 7.

Miszczak, K. (2010). Regionalny wymiar światowego kryzysu w Polsce. Biblioteka Regionalisty, 10, 137-151.

Montoya, L.A., Haan, J. (2007). Regional Business Cycle Synchronization in Europe? Bruges European Economic Research Papers No. 11, College of Europe, Brugge, Natolin.

Orłowski, W. (2009). Dziesięć przyczyn kryzysu i ich analiza. W: J. Szambelańczyk (red.), Globalny kryzys finansowy i jego konsekwencje w opiniach ekonomistów polskich. Warszawa: Związek Banków Polskich.

Rutkowski, J. (1980). Formalne charakterystyki przebiegu procesu wzrostu gospodarczego - propozycje. Wiadomości Statystyczne, 9, 5-9.

Strategie przedsiębiorstw w czasach kryzysu. Analiza procesów adaptacyjnych realizowanych w podmiotach gospodarczych prowadzacych działalność na terenie Wielkopolski (2011). Poznań: Wielkopolskie Obserwatorium Gospodarcze.

Tondl, G., Traistaru-Siedschlag, I. (2006). Regional Growth Cycle Convergence in the European Union. Pobrane z: http://epub.wu.ac.at/568/ (4.07.2015).

Warżała, R. (2014). Regionalne cykle koniunkturalne w Polsce w latach 2000-2014. Zeszyty Naukowe Uniwersytetu Szczecińskiego, Studia i Prace Wydziału Nauk Ekonomicznych i Zarzadzania, 35, 2, 529-550. 
Yuill, D., McMaster, I., Mirwaldt, K. (2009). Polityka regionalna w warunkach kryzysu. Najnowsze zmiany $w$ polityce regionalnej $w$ UE $i$ w Norwegii. EoRPA 09/2, European Policies Research Centre, University of Strathclyde, Glasgow.

\title{
INFLUENCE OF ECONOMIC CRISIS ON ECONOMIC AND FINANCIAL SITUATION OF ENTERPRISES - REGIONAL APPROACH
}

\begin{abstract}
In the paper results of research on influence of world economic crisis on economic and financial situation of Polish enterprises were presented. The analysis was conducted with use of regional data in 2006-2013. An assessment was based on observation of changes of two variables: sales revenues and employment. The sample consisted only firms which have employed at least 10 employees. Applied method was similar to the proposition of competitive advantage analysis of BCG. Two business cycle indicators: Aggregate Indicator of Business Cycle developed by Polish Central Statistical Office and Economic Sentiment Indicator elaborated by Eurostat were used for identification of turning points. Additional goals of the article were regional analysis of stability and similarity of changes of economic and financial situation of enterprises. The results have indicated that there was significant negative influence of economic crisis on economic situation of Polish firms and high regional diversification of crisis effects.
\end{abstract}

Translated by Jacek Batóg

Keywords: economic situation of enterprises, regional analysis, influence of economic crisis JEL Codes: D22, E32, R11 